\title{
„V službi vere, kulture in miru«: zadnje obdobje odnosov med Rusko pravoslavno cerkvijo in Katoliško cerkvijo v Sloveniji
}

\author{
"In Service of Faith, Culture and Peace": Recent \\ Period of Relations between the Russian Orthodox \\ Church and Catholic Church in Slovenia
}

V zadnjih desetletjih so se kot simbolno in praktično izhodišče srečevanja, spoznavanja in sodelovanja med Rusko pravoslavno cerkvijo in Katoliško cerkvijo v Sloveniji uveljavile vsakoletne državne in verske slovesnosti pri t. i. Ruski kapelici. Te so v prvi vrsti posvečene ohranjanju spomina na umrle ujetnike ruske imperialne vojske, ki jih je med prvo svetovno vojno pod prelazom Vršič pri Kranjski Gori zasul snežni plaz. Odnosi med obema (krajevnima) Cerkvama se tako umeščajo v širše kulturno in mednarodnopolitično dogajanje, katerega prvotni in sestavni del je prav liturgično spominjanje pokojnih, od koder se razvija ekumensko povezovanje, vse to pa je prepleteno s prepoznavanjem skupnih korenin in grajenjem prijateljstva med dvema slovanskima narodoma, slovenskim in ruskim. Tu se ponuja tudi povezava s Srbsko pravoslavno cerkvijo, ki na omenjenih slovesnostih redno sodeluje ob navzočnosti svojih visokih predstavnikov, saj kanonično ozemlje njene zagrebško-ljubljanske metropolije zajema celotno območje Slovenije in severni del Hrvaške. V tem pogledu se je ključno zavedati dejstva, da so bili dolga desetletja in davno pred ustaljeno javno odmevnostjo slovesnosti pod Vršičem kranjskogorski domačini tisti, ki so kot človekoljubi, Slovenci in v pretežni meri tudi katoliški verniki skrbeli za pravoslavno kapelico. Zato je za Katoliško cerkev v Sloveniji 
pomembno, da se že vzpostavljenemu »ekumenskemu terenu« ne odpove in ga ne prepusti izključno posvetnim hotenjem.

Najnovejše obdobje stikov med Rusko pravoslavno cerkvijo in Katoliško cerkvijo v Sloveniji odločilno zaznamuje sprejetje blejske ekumenske izjave (Izjava za javnost ob ekumenskem pogovoru na Bledu: mirovno poslanstvo krščanskih Cerkva) julija 2016. Izjavo je mogoče opredeliti kot duhovni odmev obeleževanja stote obletnice nesrečnih dogodkov pod Vršičem, ko je Slovenijo obiskal tudi predsednik Ruske federacije Vladimir Putin. Vredno je omeniti, da je ob tej priložnosti rusko cerkveno delegacijo vodil volokolamski metropolit Hilarijon (Alfejev), vodja oddelka za zunanje zadeve moskovskega patriarhata in eden najbolj prepoznavnih sodobnih pravoslavnih teologov, katerega dela so prevedena v večje evropske jezike. Izjavo so podpisali naslednji dostojanstveniki: na ruski strani kronštatski škof in sanktpeterburški vikar Nazarij (Lavrinenko), na srbski zagrebško-ljubljanski metropolit Porfirije (Perić), na slovenski pa takratni celjski škof Stanislav Lipovšek in evangeličanski škof Geza Filo. Omenjeni dokument se izrecno sklicuje na smernice zgodovinsko pomenljive Skupne izjave papeža Frančiška in Kirila, patriarha Moskve in vse Rusije, podpisane februarja 2016 v Havani. Blejska izjava poudarja nadaljevanje ekumenskih pobud in zavzemanje za mir, spravo in prečiščen zgodovinski spomin tako v razmerju do različnih krščanskih Cerkva in skupnosti kakor tudi do evropskih narodov. Njeni podpisniki priznavajo, da kristjani v preteklosti niso bili vedno graditelji miru, o čemer pričujejo številna preganjanja drugače verujočih in tudi primer prve svetovne vojne, ki je bila največji spopad znotraj krščanskega sveta dotlej. Prav zaradi takih izkušenj in vse večje uničevalnosti vojskovanja so krščanske Cerkve v 20. stoletju odločneje stopile na pot miru. Zavedajo se, da je mir najprej»božje delo in božji dar«, kar se odraža ob vsakem bogoslužju, v katero je nujno vtkana prošnja Bogu za mir.

Naslednji korak v poglabljanju odnosov z Rusko pravoslavno cerkvijo predstavljajo ekumenski pogovori v cistercijanski opatiji v Stični julija 2019. Takrat je rusko delegacijo vodil peterhofski škof in sanktpeterburški vikar Siluan (Nikitin), ki opravlja tudi službo rektorja Sanktpeterburške duhovne akademije, druge največje teološke fakultete na kanoničnem ozemlju moskovskega patriarhata. Škof Siluan je med drugim izrazil željo po vzpostavitvi uradnih stikov med Sanktpeterburško duhovno akademijo 
in Teološko fakulteto Univerze v Ljubljani, čemur sta z veseljem pritrdila škof Lipovšek in takratni dekan Teološke fakultete Robert Petkovšek. Zagrebško-ljubljanski metropolit Porfirije, ki hkrati opravlja službo profesorja na Pravoslavni teološki fakulteti Univerze v Beogradu, je v tem kontekstu poudaril pomembnost tradicionalne zavesti o neločljivi povezanosti med teologijo, molitvijo in Cerkvijo. Nadgradnjo in uresničitev ekumenskih pogovorov v Stični prinaša sporazum o trajnem sodelovanju med Teološko fakulteto in Sanktpeterburško duhovno akademijo, ki je bil sklenjen novembra 2020. Sporazum omogoča individualne študijske in raziskovalne izmenjave profesorjev in študentov višjih letnikov, sodelovanje na znanstvenih srečanjih in skupne objave. Vzpostavitev uradnih stikov ima pomembno simbolno razsežnost, saj Teološka fakulteta in z njo Katoliška cerkev v Sloveniji dobiva prvega akademskega sogovornika iz Vzhodne Evrope, s čimer krepi svojo zavezanost pristnemu ekumenskemu dialogu na znanstvenoizobraževalnem področju.

Sodobne katoliško-pravoslavne odnose in njihove izpeljave znotraj Ruske pravoslavne cerkve, kakor se odražajo v različnih dokumentih, dogodkih in javnih odzivih njenih visokih predstavnikov, je mogoče povzeti s prepoznavanjem določenih ponavljajočih se tem. Prvo temo in hkrati pomemben napredek na področju katoliško-pravoslavnega dialoga predstavlja kontinuiteta pontifikatov Benedikta XVI. in Frančiška, ko se ruski pravoslavni strani zdi, da se je Katoliška cerkev verjetno dokončno odpovedala uniatski metodi. To je povezano z dejstvom, da sedanji Rim v javno manj izpostavljeni meri kakor v času Janeza Pavla II. podpira želje in prizadevanja Ukrajinske grškokatoliške cerkve, ki jo Ruska pravoslavna cerkev razume kot »moteč« dejavnik v zgodovini katoliško-pravoslavnih odnosov na območju Vzhodne Evrope, njen ponovni razcvet po razpadu Sovjetske zveze pa vsaj nekoliko pristransko prikazuje kot politično pogojeno »širjenje» na tradicionalno rusko pravoslavno kanonično ozemlje v okviru Ukrajine in Belorusije. Podobno previdno ravnanje Katoliške cerkve odraža redkost njenih uradnih stališč do Ruske pravoslavne cerkve, zaradi česar ni mogoče govoriti o katoliškem vmešavanju v aktualni pereči spor med moskovskim in konstantinopelskim patriarhatom glede vzpostavitve avtokefalnega in enovitega pravoslavnega cerkvenega telesa na ozemlju Ukrajine. Bistvo težave je v temeljno različnem pogledu na Pravoslavno cerkev Ukrajine, ki od leta 2019 ob podpori ukrajinskih državnih oblasti nadomešča prejšnji samooklicani kijevski patriarhat, katerega nastanek sega v leto 1992. 
Omenjena organizacija po mnenju Moskve deluje v nasprotju s kanonično splošno priznano in po številu duhovnikov močnejšo Ukrajinsko pravoslavno cerkvijo s statusom avtonomije (ne pa avtokefalnosti), ki spada pod okrilje moskovskega patriarha. Verska in politična trenja so se v zadnjem obdobju zaostrila vse do prekinitve evharističnega občestva znotraj pravoslavnega sveta. Tu na enem bregu stoji Moskva, ki jo potihoma podpira večina pravoslavnega episkopata med štirinajstimi obstoječimi avtokefalnimi Cerkvami, na drugem pa stojijo Konstantinopel, aleksandrijski patriarhat, atenska in ciprska metropolija, ki zagovarjajo legitimnost svojega priznanja Pravoslavne cerkve Ukrajine. Večje zaupanje pravoslavne Moskve do katoliškega Rima se kaže tudi v skupni podpori verski svobodi in tradicionalni družini, za katero je značilno, da v zahodnem svetu izgublja svoj (normativni) pomen. S tem je povezano tudi prizadevanje za pomoč preganjanim kristjanom $\mathrm{v}$ arabskih in drugih večinsko muslimanskih državah, ki jim zahodni politiki in mnenjski voditelji ne posvečajo veliko pozornosti. Tretjo temo, pri čemer se trenutno zdi, da jo bolj od Rima izpostavlja Moskva, pa je mogoče prepoznavati v opozorilih ruskih pravoslavnih dostojanstvenikov o nevarnosti take sekularizacije, o kateri ni več mogoče trditi, da prihaja zgolj »od zunaj«, temveč (lahko) poteka tudi znotraj Cerkve same. Omenjena obrambna drža se med drugim kaže v podpiranju kakovostne, a hkrati z izročilom in molitveno-liturgičnim Življenjem usklajene teološke izobrazbe, kar je bilo mogoče slišati tudi v okviru ekumenskih pogovorov v Stični. 